International Journal of Linguistics, Literature and Translation (IJLLT)

ISSN: 2617-0299 (Online); ISSN: 2708-0099 (Print)

DOI: $10.32996 / \mathrm{jjllt}$

Journal Homepage: www.al-kindipublisher.com/index.php/ijllt

IJLLT

\title{
Challenges of Teaching Literature-in-English in Secondary Schools in Borno and Yobe, Nigeria
}

Muhammad Dahiru, Ph.D.

Lecturer, Department of English, Yobe State University, Damaturu, Nigeria

Corresponding Author: Muhammad Dahiru, Ph.D., E-mail: mohdahiru@yahoo.com

ARTICLE INFORMATION

Received: November 05, 2020

Accepted: December 14, 2020

Volume: 3

Issue: 12

DOI: $10.32996 /$ ijllt.2020.3.12.27

\section{KEYWORDS}

Literature-In-English, Secondary, challenges, implications

University admissions

\section{ABSTRACT}

This paper investigates challenges of teaching Literature-in-English in secondary schools within Yobe and Borno states in north-eastern Nigeria, and the impact this has on university admission requirements. A core requisite for admissions into B.A English and LL.B. in all Nigerian universities is an O' level credit pass in SSCE or its equivalent in Literature-in-English. This poses a major challenge to many candidates from Yobe and Borno States due to either the non-teaching or the inability of the students to pass with the required credit in the end of secondary school examinations. Adopting a mixed-method approach, the paper investigates reasons that bring about these problems within the period 2009 - 2019. Quantitative and qualitative approaches, through questionnaires and interviews, and Consensus Workshop, through Focus Group Discussion (FGD), were adopted to gather the data. The paper finds and concludes that socio-cultural factors, unavailability of effective and specialist teachers and gender issues were the major reasons for the non-teaching of the subject and the failure of students in public secondary schools to pass with credit in the two states. The paper recommends amenable measures to be taken to address these problems and challenges.

\section{Introduction}

For an admission into any university in Nigeria, a candidate must obtain at least credits in five subjects, including English Language and Mathematics, in the SSCE or its equivalent examination (Oguguo and Uboh, 2020). The core requirement for admission into any B.A. English or LL.B. course is an $\mathrm{O}^{\prime}$ level credit pass in Literature-in-English. It is the condition for both UTME (Unified Tertiary Matriculation Examination) and DE (Direct Entry) admission through the Joint Admissions Matriculation Board (JAMB) (Orobosa, 2019). But, many candidates from north-eastern states of Yobe and Borno have been unable to produce this credit pass between 2009 and 2019. In this paper, unmapped probable factors responsible and the impact this has on filling their quota in University of Maiduguri and Yobe State University, within the two states, are investigated.

Yobe state was carved out of the defunct Borno state on $27^{\text {th }}$ August 1991. As north-eastern states of Nigeria, both were bedevilled by insurgency and educational backwardness for more than a decade. They have generally been regarded as Educationally Less Developed State(s) (ELDS) because going by the indices annually released by regional and national examination bodies such as WAEC, NECO, NABTEC and JAMB, Borno and Yobe had always been among those at the bottom rung of the ladder as regards getting the required five credits (Utibe \& Agwagah, 2015). Yobe State came last in the 2015 national ranking on SSCE examination. With a total of 14,784 candidates that comprised 10,807 males and 3,977 females who sat for the examination in the state, only $4.37 \%$, amounting to 646 candidates, obtained the required five credits. Abia State came top with $63.94 \%$ as 33,762 of its 52,801 candidates that sat for the examination got the required five credits. Borno State occupied the $25^{\text {th }}$ slot out of 37 having 5,347 candidates getting the required credits out of the 21,695 that sat for the examination. Anambra State came second with $61.18 \%$, amounting to 28,379 candidates getting the five credits out of the 46, 385 candidates, while Edo state that came third on the scale scored $61.05 \%$ with 38,052 candidates getting the required five credits out of the 62, 327 candidates that sat for the examination (Abah, 2016). The situation of Yobe and Borno remained unchanged between 2016 and 2019 (National Bureau of Statistics [NBS], 2019).

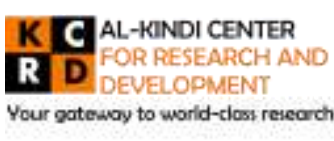

Published by Al-KindiCenter for Research and Development. Copyright (c) the author(s). This is an open access article under CC BY license (https://creativecommons.org/licenses/by/4.0/) 
In addition, Yobe state recorded the highest non-education rates of $83.3 \%$ male and $85.3 \%$ female in the country in 2013 (National Population Commission [NPC], 2014). This pathetic situation was further worsened between 2013 and 2016, a period when Boko Haram insurgency and school attacks were at the peak in the state. The atmosphere of insecurity and deaths of so many students and teachers in schools greatly affected enrolment and attendance into all levels of education, and impacted on quality of teaching and learning in all spheres (Abdulrasheed \& Obioma, 2015; Abdullahi \& Terhemba, 2014). So, insurgency has been, generally, considered as the major factor that brings about this dismal picture in the two states.

Apathy to western (formal) education by parents has also been cited as one of the major factors that significantly influenced educational backwardness in these two states (Gabriel, 2012). Literacy and school attendance levels were very poor in Borno state in the past one decade as it recorded the lowest education indicators in Nigeria. The 2010 National Literacy Survey revealed that adult literacy in Borno stood at $58.6 \%$ compared to $71.6 \%$ nationally. A report by Nigeria Education Data Survey (NEDS) in 2015 revealed 'only 16\% of parents or guardians sampled in Borno State were literate, compared to $28 \%$ in the Northeast and a national literacy rate of 47\%' (Famuyiwa-Alaka, et al., 2017). Indices on educational attainment, such as numeracy, stood at $24.6 \%$ compared to $54.5 \%$ for Nigeria as a whole in the 2015 NEDS. Furthermore, the State 'lags behind other states when it comes to literacy and numeracy rates and consistently ranks among the five poorest performing states in the country' (Famuyiwa-Alaka, et al., 2017). So, invariably, the effect of Boko Haram insurgency and parents' apathy to formal education remained the most cited probable reasons for non-teaching in all facets in Borno and Yobe states (FamuyiwaAlaka, et al., 2017; Isokpan \& Durojaye, 2016; Joda \& Abdulrasheed, 2015).

As the Kenyan social, political, environmental activist and 2004 Nobel Peace Prize winner Wangari Maathai once said, it is the little things that the citizens do that brings about a change and development, and her 'little thing' had been planting trees. The 'little thing' that this paper contributes is enormous. It expands the scope of frequently cited factors, such as insecurity and apathy, as responsible for failing examinations in Borno and Yobe States to other more probable unexplored causes and sought to proffer amenable recommendations to address them.

\section{Aim and Focus of the Paper}

The aim of this paper is specifically to investigate the problems or challenges of teaching Literature-in-English in public secondary schools in Yobe and Borno states and the impact this has on university admission requirements into B.A English and LL.B in the two states. This is to be achieved through:

(i) Determining the actual percentage of indigenes of Borno and Yobe states that had found places in BA English and LL.B. courses in University of Maiduguri and Yobe State universities between 2009 -2019;

(ii) Investigating effective teaching or non-teaching of Literature-in-English as a subject in public secondary schools in these two states;

(iii) Examining the probable relationship between religious, socio-economic and cultural factors and the non-teaching of literature in public secondary schools in the two states;

(iv) Proffering amenable measures to be taken into consideration in order to reverse the trend for the better for national development.

In order to achieve these objectives, the paper attempted to answer these research questions:

- What is the average percentage or ratio of candidates from Yobe and Borno states who got admitted into B.A English and LL.B. in University of Maiduguri and Yobe State University within the last 10 years?

- What are the various factors responsible for the dearth of teaching Literature-in-English or otherwise in public schools in these two states?

- Is there any connection between socio-economic, cultural and religious values and the problem of teaching Literature-in-English in the two states?

- Are there any amenable measures to be taken in order to address the problem of non-teaching of literature or otherwise in public schools in these states?

\section{Literature Review}

The importance of English language and Literature-in-English teaching is widely acknowledged in studies (Novianti, 2016; X Nwodo, 2011; Onukaogu, 2002; Eagleton, 1996; Cullinan, 1993; Ogden, 1967). As Novianti (2016) stated, the major objectives of teaching literature is promoting students' literary and social skills as well as fostering their liberal, ethical and human attitudes. Most importantly, literature provides the necessary information and knowledge about culture, society, tradition and language of the people. As Onukaogu (2002) also observed, Literature-in-English develops students' capacity for discrimination, judgement and decision on a given phenomenon from others' experiences. It allows students make 
connections between the content of the literary work they study and other experiences they may encounter in life. It is based on this reason that while a credit pass in English language is a mandatory requirement for all candidates seeking admission into Nigerian universities and other tertiary institutions, a credit pass in literature is specifically mandatory to those seeking admission for LL.B., largely due to the critical and analytical skill required in the law profession, and for B.A English and literary studies courses.

There is no denying the fact that Boko Haram insurgency has, in no small measure, militated against educational development in northeast Nigeria for the past one decade (Joda \& Abdulrasheed, 2015). The insurgency has increased the number of out-of-school children and nonattendance into formal education in the region (Oladunjoye \& Omemu, 2013). Over 300 school buildings, furniture and equipment were destroyed by the Boko Haram insurgents in Yobe state alone (State Emergency Management Agency [SEMA], 2016). In July 2012, Yobe Children's Academy in Damaturu was the first private secondary school in the state to be attacked by Boko Haram. One teacher was killed and 32 classrooms and 9 school offices were destroyed. The school reopened after 3 months, but only a quarter of the students returned. In 2013, an attack on students in their dormitory in GSS Mamudo claimed the lives of more than 50 students. In the same year more than 50 students in College of Agriculture Gujba faced the same fate. In 2014, more than 40 innocent students of FGC Buni Yadi were killed in their hostels. In 2015, a suicide bomb attack in GSS Potiskum also claimed the lives of 47 teachers and students and wounded 12. GSS Damaturu was also attacked and up to 10 teachers and students lost their lives, some at the spot and others later from their injuries. The attacks culminated with the abduction of the GGSS Dapchi girls in 2018 in the state. School environments in Yobe state continued to be insecure up to the end of 2020. Studies often cited such state of affairs in the state as the main factor responsible for poor students' performances in national examinations (Atsua \& Abdullahi, 2015). Failure of students to pass Literature-in-English in the SSCE examination may, therefore, be dismissed as largely due to the activities of the insurgents, which generally affected teaching and learning in the state.

The case is the same in Borno State, where the picture was even worse than in Yobe state. Between 2009 and 2019, virtually education and business of teaching and learning were halted in northern and southern parts of the state. School buildings, teachers and pupils continued to become targets of Boko Haram attacks. The insurgency has claimed the lives of about 611 teachers and 314 school children between 2012 and 2016. Many more teachers and students were either incapacitated and would no longer go back to the classrooms or had fled the state (Segun, 2016). On June 19 2013, Boko Haram attacked Ansarudeen School in Maiduguri, killing 19 students writing exams (British Broadcasting Corporation [BBC], 2013). Success International school also suffered several attacks between 2009 and 2013. In September 2012 a teacher in Mafoni Government Day Secondary School was killed in an attack to the school. Mohammed Goni College of Legal and Islamic Studies was also burnt down despite being an Islamic College, and one which the commander of the Boko Haram had attended (Human Rights Watch Report, 2016). The abduction of the GGSS Chibok girls in 2014 was the watershed; teachers and students abandoned schools for fear of their lives in almost all the public schools in these parts of the state (Oke, 2015; Olamilekan, 2014). These and many more attacks in Bama, Konduga, Mungono, Gwoza, Damasak etc made attending schools almost impossible.

Apathy to formal education in these two states is also severally cited as the major cause of educational underdevelopment, absence of teaching-learning activities and failing national examinations in the two states. Attendance in primary and secondary schools in the northeast region is the lowest in the country. According to Yobe State Primary Education Board [SUBEB] (2012\} indices, there were 1,041 primary schools and 29 pre-primary schools feeding 168 lower secondary schools in the state, which served an estimated 1 million students. These were supposed to be feeding the senior secondary schools and ultimately the universities. However, about $83.7 \%$ of children in the state between 7 and 14 years of age were out of school. In 2013, a total number of 824,978 children between the ages of 7 and 14 were estimated to be out of school in the state, which included 443,112 females and 381,866 males. About $80 \%$ to $90 \%$ of these children that were of school age were out of school in the rural areas of the state compared to about $30 \%$ to $50 \%$ in the urban areas at that period. There were about $64 \%$ of male literacy and above $70 \%$ for the female urban population. However, female literacy was only $2 \%$ and male literacy was only 5\% in the rural areas (Famuyiwa-Alaka, et al., 2017). Taking these figures together, it could be concluded that even prior to Boko Haram insurgency, the highest national out-of-school population was in these two states.

A study by Gubair and Samia (2019) in Sudan offers a critical perspective that applies to the situation in Borno and Yobe states. This is mainly due to two reasons: the religious and cultural milieus of Sudan and North-eastern Nigeria share semblance. One of their findings is the issue of cultural backgrounds and linguistics competence of the students as a factor that affects teaching literature-in-English. In Sudan, as Gubair and Samia revealed, English is not the official language and so 
candidates find it very difficult to deconstruct a literary piece and appreciate it. While English is the official language in Nigeria, and invariably of Borno and Yobe states, the educational backwardness has made the students' level of competence in English far below the standard to enable them read a literary text effectively and critically appreciates it. Yobe recorded $0.90 \%, 0.94 \%, 0.88 \%, 0.85 \%, 1.09 \%$ for years $2014,2015,2016,2017$ and 2018 respectively with a mean percentage of $0.93 \%$ and Borno recorded 14.14\%, 28.52\%, 55.55\%, 43.82\% and 20.64\% for years 2014, 2015, 2016, 2017 and 2018 respectively with mean percentage of $32.53 \%$ in the overall SSCE examinations within the last decade (Oguguo \& Uboh, 2020). So, the same challenge in Sudan can be attributed to Yobe and Borno states' candidates, who are always last in national examinations, and especially failing to get the required credit pass in English (Abubakar \& Kaigama, et al, 2019)

Other studies revealed diverse reasons for the challenges in teaching Literature-in-English in secondary schools or universities across the world. Students, teachers, the society and culture, the curriculum have all been cited as the reasons. Other relevant findings include, among others, cultural background of the students, language competence of the students, the selection and availability of literary texts, teachers' competence, the curriculum and students' interest and motivation in Sudan (Mohammed, 2015; Ali, 2015; Al-Faki, 2014; Ali, 2001; Gubair \& Samia, 2019; Mohamed, 2015) Bangaladesh (Hassan, 2018), Indonesia (Novianti, 2016), Turkey (Kizildag, 2009;Yavuz, 2014, Işıklı, \& Tarakçıŏlu, 2017), India (Sarkar, n.d), Finland (Dornye, 2007), Soviet (Ionin,1989), Nigeria (Ichu, 1989; Fatimayin, 2004; Adegbile, 2016; Kaigama et al., 2019) and Saudi Arabia (Hussein \& Al-Emani, 2016),

There are, however, virtually few or no studies in north-eastern Nigeria that focused on challenges and problems of teaching literature-in-English in secondary schools and the impact this has on university admission. The current study aims to contribute a perspective from Yobe and Borno States. The reviewed literatures are further discussed in relation to the findings from the responses gathered in the current study.

\section{Methodology}

The paper adopted a pragmatic approach for the current study. A mixed-method, which includes quantitative and qualitative approach through questionnaires and interviews, and Consensus Workshop through Focus Group Discussion (FGD) was adopted as the pragmatic approach to gather the data for the discussion. This approach was adopted on the assumption that "no investigative strategy is essentially superior to another" (Saunders et al., 2012, p.141). Pragmatists assess quantitative and qualitative techniques equally, and promote that the amalgamation of both assists in consideration of any study. So, this paper adopted a "triangulation", which is expected to provide a bird-eye view on a problem from different perspectives (Saunders et al., 2012). The approach has provided authentic, dependable and enlarged information on the research problem through qualitative and quantitative data collection and analysis.

Quantitative data was collected through questionnaires and interviews administered to sampled populations with the view to decrease the possibilities of reaching deceitful endings (Yin, 1994). These were mixed with a qualitative data extracted through narratives, unstructured interviews, observations and first-hand information, and consensus workshops from the sampled population. The following major methods were adopted for the research in order to answer the research questions and to reach a reliable and valid conclusion:

\subsection{Case study}

Admissions into Yobe State University and University of Maiduguri were used as case studies. The problems of low number of candidates admitted into BA English studies and LL.B. between 2009 and 2019 were ascertained from the heads of English and Law departments and the admission officers in these two institutions. The case study provided both quantitative and qualitative data for the analysis. As it is, a case study entails 'applying numerous sources of facts to carry out an experimental research of a specific recent experience inside its genuine life framework' (Brown, 2008).

\subsection{Consensus Workshop}

A consensus workshop was run for sampled teachers and students from four higher institutions in Borno and Yobe states. Consensus Workshop is a Focused Conversation in a specialised way in order to help a group reach consensus on a question (Gibraith, 2018). The consensus workshop involved putting the participants in groups to brainstorm on the research questions. Their responses in smaller groups were shared, one at a time, and posted to a larger group. The larger group then clustered the responses as the findings, by first arranging them in related themes or concepts. These major findings were then deliberated upon to come up with major related findings as the answers to the research questions. This method offered both a qualitative and quantitative method to investigate the impact of a problem and building a consensus around amenable measures to be taken to address it. 


\subsection{Unstructured Interviews and Questionnaire}

School administrators in ministries of education from Yobe and Borno states, principals and their vice principals and selected female teachers of Literature-in-English in sampled secondary schools in the two states, as well as heads of departments of English and Law from the four selected higher institutions in Borno and Yobe States were interviewed using an unstructured interview and questionnaires. The items of the questionnaire and the interviews were structured from the research questions. Responses gathered through the interview were recorded and later transcribed as qualitative data. The discussion in the interview was fully converted to printed document for analysis. The responses from the questionnaire were also extracted, grouped and used as quantitative data for the discussion of the findings.

\subsection{Sampled Population}

The research was limited to some selected secondary schools and institutions in Borno and Yobe states. Due to insecurity, the mapped 80 secondary schools 4 higher institutions and 16 private secondary schools could not all be accessed. Some of these mapped schools were either destroyed, and so remained non-functional, or are still inaccessible due to the insurgency. In addition, some of the respondents in the ministry and the institutions selected have bounds in revealing confidential part of their activities, particularly in relation to a failure from their own part. That informed keeping the names of some institutions, ministries and the participants confidential in this study. The result from the sampled population was discussed as the finding to reach a conclusion at a point of saturation.

\section{Discussion of Findings}

Data collected are discussed based on the research questions and the target population responses in order to achieve a particular objective. In other words, a research question is taken to formulate the items of a questionnaire, interview or the FGD topics in relation to the stated objective. This is answered, through the appropriate method adopted, by the responses of the population.

\subsection{Research Question 1: What is the Ratio of candidates admitted into B.A English and LL.B. Courses?}

The first Research Question demands to find out, through interviews and questionnaires, the ratio of candidates from Borno and Yobe states admitted into B.A English and LL.B. in University of Maiduguri and Yobe State University in relation to candidates from other states in Nigeria. This question was posed to the admission officers and heads of departments of English and Law in the two universities. The objective is to determine the actual percentage of indigenes of Borno and Yobe states that found places in the two courses between 2009 and 2019.

In Yobe State, the admissions officer admitted that every year the number of candidates applying for B.A English dwindles. Most candidates with $O^{\prime}$ Level Credit pass in Literature-in-English had originally applied for either Sharia or Civil Law LL.B course within the past 10 years. The head of English department confirmed that in 2018, only 60 candidates were admitted while only 37 candidates were admitted into B.A English course in 2019. About $90 \%$ of these admitted students attended private schools, and so were able to produce the required credit in Literature-In-English. The Admissions officer revealed that from 2009 to 2019, two-third of all the candidates that got admitted into B.A English course could not be admitted for the LL.B. due to insufficient spaces. As the head of the department Law confirmed, the maximum number of candidates for the LL.B. was about 50 in the past two years, and so those that could not get place were invariably recommended for a B.A English degree course. Out of these few number of admitted candidates into LL.B., the average percentage for Yobe indigenes stood at $55 \%$, while $45 \%$ came from non-indigenes at JAMB's green belt zone. For the English department, the tally is the same, or even less given the few number of candidates admitted.

University of Maiduguri, being a Federal and $2^{\text {nd }}$ generation university, has large population of candidates for the B.A. English and LL.B. courses. The ratio of Borno and Yobe state candidates for these courses, however, had been about 1:20 for indigenes and non-indigenes. Yobe and Borno state applicants are considered indigenes in the university due to the federal policy of 'catchment area' (Adeyemi, 2001). Notwithstanding this advantage over other candidates from states outside this 'area', the number of candidates admitted into these two courses remained dismally low over the last decade. This is also despite the insecurity situations in the state, which would have deterred and discouraged candidates coming from other states than Borno and Yobe to Maiduguri. Boko Haram insurgency, therefore, did not tilt the scale of number of admitted candidates into these courses in favour of candidates from Borno and Yobe, largely because they failed to produce the required credit pass in Literature-in-English for admission to fill their quota. 


\subsection{Research Question 2: Is Literature-in-English Taught as a Subject in Public Secondary Schools?}

Items of this question were directed at the principals and vice principals academic of the selected secondary schools in Yobe and Borno states. The items were also directed at the two school administrators in the two states. Their responses on the items were collated and summarised at the point of saturation to answer the question.

\subsubsection{Is Literature-in-English in the Curriculum?}

This item of the question investigates whether Literature-in-English is stipulated in the Nigerian National Curriculum for secondary schools. All respondents agreed that Literature-in-English is in the curriculum. But, as stipulated by Nigerian National Policy on Education (NPE), it is merged with the English language as English Studies at the Junior Secondary School (JSS) level. But at the Senior Secondary School (SSS) level, it stands as a separate subject with 3 periods per week allocation. At this higher level, Literature is for the Arts students only and the Science students have the liberty to choose it or Geography in its stead. According to the National Policy on Education document, every final year student of a secondary school shall register these six core subjects: (i) English language (ii) Mathematics (iii) A major Nigeria language (iv) One of Biology, Chemistry, Physics or Health Science (v) One of Literature-in-English, History, Geography, or Religious studies and (vi) A Vocational subject in the national examinations (NPE, 2004).

The curriculum designers failed to see the significance of Literature to the sciences; hence it is made optional for them. But, it significantly supports the teaching of science subjects (Wilburne \& Napoli, 2008; Gastón 2008). As Cohen and Wendt' (1993) equation puts it, 'mathematics + Literature $=$ Success' (p. 57). Lapp and Flood (1993) also concurred with this, claiming that 'the use of literature as a compliment to science textbooks can help students develop both skills and motivation to pursue scientific inquiry with enthusiasm and success' (p. 73). Literature-in-English should not have been restricted to the arts and humanities only; it is equally important to the sciences. In addition, it should not be for the senior grade only but should be taught even at the lower JSS grade as it is an important instrument that acquaints learners with the necessary skills to learn the English language (Nwodo, 2011; William, 1990; Mohammed, 2015; Ali, 2001). It as well transforms and intensifies ordinary language (Eagleton, 2011), and as Cullinan (1993) puts it, it helps students to learn language, learn through language and learn about language. So, it is as significant for the JSS as it is for the SSS students.

\subsubsection{Is Literature taught in all Secondary Schools in the state?}

Despite its provision in the national curriculum, only two (2) public secondary schools, out of the sampled secondary schools in Yobe state teach Literature-in-English as a subject. There are 47 government secondary schools in the state, out of which 7 are science-based secondary schools and 2 Government Colleges (also called Unity Colleges), one for girls and one for boys. In addition, there are two (2) Federal Government Colleges, one for the boys and one for the girls. There are also 23 registered private secondary schools, making a total of 72 senior secondary schools/colleges in the state as at 2019 . Out of these, only the Government Girls College and the Federal Government Girls College teach literature-in-English. It was taught in the other boys' Federal Government College after attacking it in 2014 and killing scores of students the college remained closed and non-functional. Literature was also taught in the other boys' Government College in the past but between 2009 and 2019 the subject was no longer taught due to lack of teachers. This corroborates Ogunnaike, (2002) assertion that generally there are no sufficient teachers to handle literature teaching in Nigeria. However, all the private schools sampled revealed teaching Literature-in-English but the subject is usually handled by unqualified teachers, which invariably result in poor and ineffective teaching (Vincent, 1979). There is no functional teaching and learning in northern Borno due to the activities of Boko Haram. The bulk of the discussion from within Maiduguri and few selected schools in southern Borno revealed that Literature is taught in most of the private schools and two public secondary schools within Maiduguri.

\section{2 .3 Is it significant as a subject?}

There are mixed responses on this item. One school administrator claimed that it is not relevant given the current global trend, in which sciences, ICT and management courses are the favourites. The other school administrator, however, sees it as important given that it prepares students to be effective writers and communicators. More than $60 \%$ of the principals and vice principals sees the relevance of Literature-in-English for the development of students. 20\%, however, see no relevance, especially to sciences and management career paths. The other $20 \%$ see no relevance even to those aspiring for professions in the humanities.

As contained in the National Policy on Education (NPE), one of the goals of secondary education in Nigeria is to "raise a generation of people who can think for themselves, respect the views and feelings of others [and] respect the dignity of labour (NPE, 2004, p.18). Literature provides or lays the foundation for all these. As Ryan and Ryan opined, literature is a reflection of any society; it mirrors human condition as well as presents ideology and challenges it while making readers or 
participants think about all these. It also recreates another world seen through reading literary material. Literature, therefore, develops individuals and the nation by bringing about empowerment, pleasure, acculturation and general knowledge on different things and ideas. Hence it should be considered as significant.

\subsubsection{Are there qualified teachers to teach it, if taught?}

There are no sufficient teachers according to all the principals in the secondary schools, while the school administrators said there are sufficient teachers to teach all Arts subjects in all the functional secondary schools. The principals and their vice principals, however, revealed that the available teachers that teach in the two public schools are mainly provided through Federal and State government graduate teachers schemes, including NPOWER and other casual and voluntary teachers. The respondents in the FGD disclosed that there are very few permanent NCE and B. Ed. graduates of English literature to teach in the secondary schools across the two states.

The participants of the FGD also revealed that most available teachers in the private secondary schools are not competent as they did not specialise in English Literature but in English Language teaching. Some of such graduate teachers are not even Language specialists but from the humanities and are assumed capable to teach the literature subject. Responses from the FGD also reveal that most of these teachers adopt inappropriate methods to teach the subject, which is understandable given their background and specialisation are not necessarily in B.Ed. Literature. As Labo-Popoola observed, the attitude of the teacher as well as his competence in handling literary texts will determine his output in the class and the attitudes of the students to the subject (Labo-Popoola, 2020). The available teachers do not apply the appropriate method of teaching but use whatever method available. This concurred with Ogunaike's claim that teachers of literature in the secondary schools mostly adopt 'take your book and read approach' (Ogunaike, 2002). The available teachers don't apply good methods and approaches but use techniques such as 'take your book and read approach' (Ogunnaike, 2002).

As further discussed in the FGD, many students in colleges of education and the universities do not consider humanities an area of specialisation to pursue in life. This brings about dearth of teachers, including of literature, in secondary schools in the state. This view is shared by Fakeye (2011) in his study of general decline in enrolment into literature-in-English classrooms. The responses of principals and vice principals on the unavailability of teachers and the FGD responses on their incompetence all confirmed that the few available teachers are not competent. A lot of these teachers engaged with private secondary schools to teach Literature-in-English have either lost their lives or had left the two states between 2009 and 2019 due to the activities of the Boko Haram. In addition, most NYSC 'corps members' or graduates from other states that either completed their NYSC service year and stayed behind to take up appointments had fled the two states. The activities of the insurgency have also discouraged prospective NYSC 'corpers' coming to the two states.

The teaching of literature in the secondary schools, as discussed through the FGD, is very significant as it develops the capacity of the students and makes them learn and build from the experiences of others for their own development in life. As Onukaogu similarly observed, students can use literature to connect with the contents of their curriculum and with other experiences they encounter in life (Onukaogu, 2002). So literature should be taught from the lower grade as it contributes to students' development (Ogden, 1997). As observed by the participants also, there is no dynamic policy on ground as regards teaching functional literature for students in the secondary schools. This is corroborated by Nwodo (2011).

\subsubsection{Are there enough resources?}

Both school administrators and the principals with their vice principals agreed that there is dearth of resources required to teach literature-in-English in all public secondary schools. The activities of Boko Haram had destroyed lots of resources for all subjects in the schools. The FGD revealed that a challenge, as regards resources, is that different literary texts are required by the different examination bodies for the same exam every year. It was agreed by the participants that it is very difficult for the authorities or the parents to provide all the texts for the students to read. In addition, the participants agreed that reading the texts selected for the literature examination doesn't really teach the children the necessary personal, social and intercultural character that the texts were meant to. The finding on too many recommended texts to cover in a literary class corroborates the findings of Ogunnaike (2002). The participants also identified the social media as a factor that affects reading culture among the students. The students find reading lots of texts difficult, particularly if this is accompanied by a bad or poor teaching approach and difficult or uninteresting texts that are not relevant to the cultural background of the learners. 


\subsection{Research Question 3: Is there any probable relationship between religious, socio-economic and cultural factors and the non-teaching of literature in public secondary schools in Borno and Yobe states?}

This question is answered by teachers and students through the FGD. The participants discussed this question in an organised formal setting, with the aim of reaching a consensus. As the procedure requires, each item was discussed in smaller groups before coming back to the larger group to agree on the answer to the question. The items discussed were as follows:

\subsubsection{Religion}

Religion was accepted in the larger group as factor that affects the teaching of Literature-in-English in the secondary schools in the two states. The discussion from the smaller to the larger groups revealed that Islamic extremism has significantly affected the teaching of not only Literature-in-English but all subjects in the curriculum. Boko Haram ideological stand on formal Western Education was considered as a general threat to educational development in the two states. A group in Borno shared an experience in which, during one of the sermons by the commander of the extremists group, he insinuated that the symbol + in Mathematics represents the Christian Cross, and so the whole aim of formal western education is to Christianise the people of the state. The concept of 'Future Tense' in English is, also according to the ill-informed scholar, an attempt to teach children about tomorrow, which is only a divine providence to say what would happen tomorrow. This ignorance about western education is more pronounced on Literature-In-English that requires learners to read texts with cultures and behaviours of the characters completely alien and unacceptable to their community. A participant gave an example of reading Chinua Achebe's Things Fall Apart, which has Igbo gods and deities, as an act of corrupting their religious values. Another observation on a novel from northern Nigeria, Climate of Corruption, opined that the novel does not promote religious values of the region but a complete means of corrupting the children's morals. The cover of the novel, bearing a picture of half-naked woman and description of sexual acts, drinking of alcohol, gambling and other vices would only succeed in corrupting the minds of the students rather than develop their capacity and make them learn and build from the experiences of others for their own development in life, as Onukaogu (2002) and Ogden (1997) may opine. The FGD also revealed that most of the female readers in the Hausa speaking areas in the two states enjoy reading the romance novellas known as Littattafan Soyayya, which flourished within the Kano Market Literature. This genre started in the 1980s in Kano, the largest Hausa city in northern Nigeria. It was a self-published literature, written and distributed mostly by Hausa female writers under strict censorship of the authorities in Kano state. The Kano State Islamic Hisbah censorship board created in 2001, however, ensured that the contents of these Soyayya novellas conform to cultural and Islamic religious dictates in the society. The action of the Hisbah revealed the general moral and religious values shared in the whole region as regard literary texts.

\subsubsection{Social and Economic Factors}

About $80 \%$ of the few FGD respondents teaching or studying literature-in-English admitted they 'accidently' found themselves teaching or learning Literature-In-English. This is revealed from each smaller group presentations on the relevance of Literature course to their social and economic life. A students' group in Borno emphasised that Literature is not a marketable course so they would have preferred other courses that pay instead of studying it and eventually end up as teachers. Both the teacher and student participants revealed they have no motivation to specialise in the subject. A participant student from Yobe explained that teachers are the least in the rung of professions in Nigeria and more specifically in the two states. So, studying B.Ed. or NCE literature is limiting one to the teaching profession. Teachers symbolise penury and destitution and are never considered models by parents in northern part of Yobe. She shared an experience from one of the junior secondary schools in the area about a father that went into a class while teaching was taking place. He asked the teacher whether the 'final prayer' for the day was said because he needed his son to drive the sheep and goats to the pasture. The teacher told the father the class was not over yet and tried to show him (the father) the significance of allowing his child to concentrate on his education instead of rearing animals every day. The reply of the father to the teacher was, 'what benefit would the education have on him or us; wouldn't he end up like you?" Participants admitted that economic importance is highly attached to all forms of education, and literature as a subject does not give that economic advantage. This finding corroborates Fakeye (2011) that revealed declining enrolment of students into literature classrooms and Fakeye (2012) on students not considering literature as a profitable career path.

The FGD further revealed that humanities are mostly considered as courses for the females. This is evident in the number of candidates admitted into B.A English and LL.B, in which the ration of male to female is 1:4. Given that the number of girls that go to school in these two states is dismally low, the number of candidates for these courses is also low. The education of many girls in these two states usually ends after completing primary school. At that time, such girls are married off and moved to their husband's houses as child-brides. As Margaret Hauwa Kassam puts it, 'very few young girls obtain secondary and tertiary education because tradition requires them to be married early in life [and so females'] chances of enhancing 
their social status seems to be jeopardized' (Kassam, 1996, p. 122). This finding corroborates Anthony (2011) on gender as a determinant of achievement in Literature-in-English among the Yoruba and Anisa (2017) finding that girls have higher achievement in literature study compared to boys.

\subsubsection{Cultural factors}

In all the Focus Group Discussions in the two states, participants reached the consensus that what makes literature unattractive is the cultural background of the learners. Texts recommended are mostly set in cultures different from the learners. This poses difficulty in the understanding, appreciation and analysis of the cultural contents if the texts. The findings from the discussion illustrated that texts that are alien to the background of the learners in the two states pose difficulties in appreciating and analysing them. A participant from Borno stated that learners would find characters in Zaynab Alkali's The Stillborn easy to follow and appreciate than they would with Chinua Achebe's, Wole Soyinka's or J.P Clark's persona or characters. Al-Faki (2014) also found this problem, revealing that studying English texts, such as Jane Eyre, Treasure Is/and, Oliver Twist do not meet the linguistic and cultural background of the students of secondary schools in Sudan. The FGD revealed that most teachers of literature are non-Muslims, so the society considers the texts they use for the subject are for the 'non-believers' only. Coupled with the activities of the Boko Haram and the mind-set of the people on apathy to formal education, the 'non-believers' teachers might have been either killed or they have fled the two states, resulting in a dearth and failure of candidates from the two states to pass the subject with a credit pass.

\section{Conclusion}

As a broad objective, the paper sets out to investigate the problems or challenges of teaching Literature-in-English in public secondary schools in Yobe and Borno states in Nigeria, and how this affects the chances of candidates from these two states getting admitted into B.A English and LL.B courses. To achieve this objective, the actual percentage of candidates from these two states admitted into these courses in University of Maiduguri and Yobe State universities between 2009 -2019 were investigated. In addition, the teaching or non-teaching of the subject in public secondary schools across the two states was also investigated. Most important, probable factors responsible for the non-teaching were investigated in relation to available findings in studies across the world. The paper found out that socio-economic and cultural factors, unavailability of qualified teachers, non-functional curriculum, lack of available and appropriate texts and resources, and gender construct issues in the two states are the factors responsible for the non-teaching of a Literature-in-English in Senior Secondary Schools in Borno and Yobe states. The study concludes that it is this state of affairs that continued to have negative impact on the chances of the candidates from these two states getting admitted into even the universities within their territories for the LL.B and B.A English courses. This finding is significant for policy formulators, administrators and other relevant stakeholders in the two states to rally upon so as to change the situation for the better. The study has expanded the scope of the existing literature that invariably cited insecurity and apathy to formal education as the immediate and remote causes of failing national examinations in the two States. Although the research was limited, to some extent, to sampled secondary schools, and by the insecurity across the two states, the responses from the population sampled consistently revealed the same findings across the schools. This leads to reaching the conclusion at a point of saturation. A further research can be done on the same challenge from the un-accessed population in the two states in order to corroborate or validate the result of the current study. In addition, challenges of teaching different subject other than Literature-in-English can be investigated in the two states or beyond, as regards university admission, in order to confirm or validate the research instrument of this study.

\section{Recommendations}

The last objective of the study is proffering amenable measures to be taken into consideration in order to reverse the trend for the betterment of the indigenes of the two states and for national development. To achieve this, the paper recommends the following.

\section{(I) Sensitisation to stakeholders}

School administrators, principals and vice principals as well as the parents that do not see value in Literature-In-English should be sensitised on the implications this has on the development of the students, the two states and the country as a whole. The findings and statistics found in this study should be provided to these stakeholders.

(II) Advocacy on all the factors

Advocacy should be provided on all the findings of this study. Students and prospective teachers in colleges of education and universities should be given guidance and counselling on the subjects they should take based on their ambitions and mission in life. Relevant government authorities should also be encouraged to employ more qualified teachers and engage more NYSC members, whose specialisation is in literature, to be sent to all public secondary schools in the two states. Examination 
bodies should also take every culture and tradition in selecting recommended texts for their examinations. There should be wide choice and options of recommended texts that would reflect different cultural codes of the diverse ethnicities in the country. The curriculum designers should see the significance of Literature to the sciences; hence it should be compulsory not optional subject in secondary schools. Hence, Literature-in-English should be taught from JSS1 up to SS3 to enable students get the rudiments to specialise in the subject area in the universities. Most importantly, girl-child education should be given a boost by encouraging more girls to go to school. If the construct that English studies, literature and other humanities are areas meant for women is anything to go by, and the mind-set cannot be easily changed, then more females should be encouraged to go to school and study these courses. In that way more indigenous teachers would be produced to fill the void of non-teaching of literature-in-English in Borno and Yobe states.

\section{References}

[1] Abah, C. (2016). Again, South-East leads in WASSCE performance chart. Punch Newspaper

[2] Abdullahi, U., \& Terhemba G.A. (2014). Effects of Insecurity on Primary School Attendance in Damaturu Metropolis Yobe State, Nigeria. JRES, 5(1), 32-38.

[3] Abdulrasheed O, Onuselogu A and Obioma U.G. (2015). Effect of Insurgency on Universal Basic Education in Borno State of Nigeria. AJER, 3(4), 490-494. https://doi: 10.12691/education-3-4-16490-494

[4] Abubakar, A., \& Kaigama, A. (2014). An Empirical Investigation into Literature-in-English as a Support to Students Improved Performance in English Language at the Senior Secondary School Certificate Examination in Yobe State - Nigeria'. Journal of Education and Practice, 5(20), 64-68.

[5] Adegbile, J. H. (2006). Evaluation of the Teachers' Communicative Skills for the Junior Secondary School English Language Teaching. JOS IH, 1(1), 140-150.

[6] Adeyemi, K. (2001). Equality of Access and Catchment Area Factor in University Admissions in Nigeria. Higher Education, 4(2).307332. http://doi.org/10.1023/A:1017965905830

[7] Al-Faki, M. (2014). Using Literature in EFL Classes: Assessing the Suitability of Literary Texts to Secondary School Students, European Journal of English Language and Literature Studies, 2(4), , 9-21.

[8] Ali, E. A. (2015) 'The Impact of Teaching English Past Tenses through Literature in Sudanese EFL Classrooms' International Journal of Applied Linguistics \& English Literature, 4(3), 1-8.

[9] Ali, M. (2001). Exclusion of Literature from Sudanese Syllabus and its Adverse Effects on the EFL Learners [Master's Thesis, University of Khartoum]. University of Khartoum Thesis and Dissertation http://khartoumspace.uofk.edu/handle/123456789/19959

[10] Anisa, A. (2017). Students' literature achievement: predictors investigation Research. REID Research and Evaluation in Education, $3(2), 144-151$

[11] Anthony, J.C. (2011). Gender as a Determinant of Achievement in Literature-in-English [Master's Dissertation University of Ibadan].

[12] Atsua, T., \& Abdullahi, U. (2015). Impact of Boko Haram Insurgency on Principals, Teachers and Students in Senior Secondary Schools in Borno State, Nigeria. Knowledge Review, 33(1), 1-8

[13] BBC (New) (2013 June 19). Nigeria militants kill school children in Maiduguri," June 19, 2013, http://www.bbc.com/news/worldafrica-22963515, (accessed October 31, 2020).

[14] Brown, D., (2008). Factors contributing to job satisfaction in higher education: the key to greater productivity and retention of a qualified workforce. Michigan: Andrews University Press.

[15] Cohn, D. and Wendt, S.J. (1993). Literature Adds Up for Math Class' In B.E. (ed). Fact and Fiction, Literature across the Curriculum. Newark DE: International Reading Association,.

[16] Chesterman, A. (1983). The Teaching of Literature to Non-Native Speakers. AFinLa:nVuosikirja, 135-142. Cullinan, B.E. (1993). 'Introduction' In B.E. Cullinan (ed) Pen in Hand: Children become writers, Newark, DE: International Reading Association.

[17] Dornyei, Z. (2007). Research Methods in Applied Linguistics: Quantitative, Qualitative, and mixed Methodologies. Oxford: Oxford University Press.

[18] Eagleton, T. (1996). Literary Theory: An Introduction. Oxford, Oxford Blackwell Pub. Inc.,

[19] Fakeye, D. O. (2011). Causes of Declining Enrolment In Literature-in-English Classroom. Gestet Vois,(5), 34-42.

[20] Fakeye, D. O. (2012) 'General Preference and Senior Secondary Schools Literature-in-English Achievement'. Cross-Cultural Communication, 8(4), 39-45.DOI:10.3968/j.ccc.1923670020120804.1163

[21] Federal Republic of Nigeria (2004) National Policy on Education, $4^{\text {th }}$ Edition (2004 Revised), Lagos, NERDC Press

[22] Federal ministry of Education (2017), Digest of Education Statistics (August 2017)

[23] Famuyiwa-Alaka, Motunrayo, Matthew P., Oladele A., Hadiza M, Abba J.M, \& Sani N (2017). Teaching in Distress: An assessment of the impact of protracted violence due to insurgence on the Primary School teaching workforce in Borno State, Nigeria. EDOREN. UKaid Available from http://www.nigeria-education.org/edoren/wp-content/uploads/2018/11/Teaching-in-Distress-Violence-ImpactAssessment-on-Teachers-Borno.pdf

[24] Fatimayin, F.F. (2004). Techniques used in Teaching Difficult Vocabulary in English Reading Passages by Senior Secondary School Teachers in Lokoja, Nigeria (Master's Thesis, University of Ilorin].

[25] Federal Government of Nigeria (2004) National Policy on Education 4th Edition Lagos: NERDC

[26] Gabriel, A. (2012). Achieving Universal Basic Education in Nigeria Since 1999: Women as Partners. Journal of Sociological Research, 3(2), 215-26. DOI: 10.5296/jsr.v3i2.3008 
[27] Gastón, L. (2008). Using Literature to Teach Maths: A Review and an Update on Using Children's Literature to Teach Mathematics. (ED503766) ERIC . https://files.eric.ed.gov/fulltext/ED503766.pdf

[28] Gibraith, M. (2018). Facilitating participation in our organisations. Top Network https://martingilbraith.com/tag/consensusworkshop/

[29] Gubair, M., \& Samia, E. (2019). Challenges to Teaching English Literature in Sudan from a Teacher's Perspective: A Case Study of Khartoum University' International Journal of Science and Research (IJSR) 8 (3), 828-835

[30] Hassan, K. M., 2018. Difficulties Facing English Teachers in Teaching Literary Texts at Higher Secondary Level in Bangladesh. English Language and Literature Studies, 8(3),15-26.

[31] Human Rights Watch. (2015) “Children and armed conflict," Report of the UN Secretary-General, June 5, 2015, par.233 http://www.un.org/ga/search/view_doc.asp?symbol= A/69/926\&Lang=E\&Area=UNDOC, (accessed April 4, 2016).

[32] Human Rights Watch (news release) (2016, March 7). Nigeria: Boko Haram Targeting Schools. https://www.hrw.org/news/2012/03/07/nigeria-boko-haram-targeting-schools,

[33] Hussein, E. A. (2016). Challenges to Teaching English Literature at the University of Hail: Instructors.Perspective' Arab World English Journal (AWEJ), 7(4),125-138.

[34] Ichu, E. (1989). An Investigation into the Problems Encountered In the Teaching and Learning of Literature in English (A Case Study of Nnewi Local Government Area). Master's Thesis University of Nigeria, Nsukka].https:///oer.unn.edu.ng/read/an-investigation-intothe-problems-encountered-in-the-teaching-and-learning-of-literature-in-english-a-case-study-of-nnewi-local-governmentarea/file.pdf

[35] Ionin, G. N. (1989). Certain Problems of Teaching Literature in the Schools. Soviet Education, 31:6, 67-81, DOI: 10.2753/RES10609393310667

[36] Işıkı, C., \& Tarakçığlu, A.Ö. 2017. Investigating problems of English literature teaching to EFL high school students in Turkey with a focus on language proficiency. Journal of Language and Linguistic Studies, 13(2), 82-95.

[37] Right to Education in Nigeria Isokpan, Aisosa Jennifer and Durojaye, Ebenezer. (2016). Impact of the Boko Haram Insurgency on the Child's. PER, 19(1), 1-43. ISSN 1727-3781. http://dx.doi.org/10.17159/1727-3781/2016/v19n0a1299

[38] Joda, F., \& Abdulrasheed, O. (2015). Effects of insurgency on Girls education in North Eastern Nigeria. European Journal of Education and Development Psychology, 3(1), 44-50.

[39] Kaigama, A., Ciroma, Z. I., \& Also, A. M. (2019). Survey into the Causes of Consistent Failure in SSCE in English Language in Yobe State: A Study of Yobe, Zamfara, Abia and Edo States' Secondary School. International Journal of Linguistics, Literature and Translation, 2(6), 470-477. Kassam, H. (1996). Some Aspects of Women's Voices from Northern Nigeria' In African Languages and Cultures 9 (2), 111125

[40] Kilzig, A. (2009). Teaching English in Turkey: Dialogues with Teachers about the Challenges in Public Primary Schools. International Electronic Journal of Elementary Education, 1(3). 187-201

[41] Labo-Popoola, S. O.(2010). The Place of Literature in the Teaching of English language as second Language. The Social Sciences, 5,1, 49-54.

[42] Lapp, D. \& Flood, J. (1993) 'Literature in the Science Program' In B.E. Cullinan (ed). Fact and Fiction: Literature across the Curriculum, Newark DE

[43] Mohammed, S. (2015). Towards Effective Values of Teaching Literature to Secondary School Students. International Journal of Science and Research, 4 (11), 2319-2322.

[44] National Bureau of Statistics (September 2019) WAEC Results Statistics (2016 - 2018) www.nigerianstat.gov.ng.

[45] Novianti, N. (2016) 'English Literature Teaching: An Indonesian Context' Indonesian Journal of Applied Linguistics, 6 (1), $42-49$.

[46] National Population Commission (NPC) [Nigeria] and ICF International (2014) Nigeria Demographic and Health Survey 2013. Abuja: Nigeria, and Rockville, Maryland, USA: NPC and ICF International. https://dhsprogram.com/pubs/pdf/FR293/FR293.pdf

[47] Nwodo, E. C. (2011). Deprivation of Literature-in-English as the missing link in Nigerian Education in the Twenty-first century: issues and prospects. Journal of the Nigeria English Studies Association (JNESA) 14(2) 89-102.

[48] Ogden, H.V.S. (1967). Imaginative Literature as a College Study. College English 29(1), 1-15

[49] Oguguo, U., \& Uche, U. (2020). State Based Analysis of Candidates' WASSCE Participation and Achievement of Five Credits Passes and Above including Mathematics and English Language in Nigeria. International Journal of Advanced Academic Research (Sciences, Technology and Engineering, 6(6), 42-53 DOI: 10.46654/ij.24889849.e6619

[50] Ogunnaike, J. (2002). Challenges of the Teaching and Learning of Literature in Nigerian Secondary Schools. In A. Lawal, I.lisugoAbanihe and I.N. Ohia (eds) Perspectives on Applied Linguistics in Language and Literature. Lagos: Stirling-Horden. 334-344

[51] Oke, R,O., \& Labeodan H.A (2015). Boko Haram Insurgence, the Chibok Girls' Abduction and the Implication for the Girl Child in Nigeria. In Ross RE and Amenga-Etego R (eds) Unravelling and Reweaving the Sacred Canon in Africana Womanhood. Lanham: Lexington Books pp 93-106

[52] Oladunjoye P., \& Omemu F. (2013). Effect of Boko Haram on School Attendance in Northern Nigeria. BJE, 1(2), 1-9

[53] Olamilekan. A. (2014). A Perusal Analyses on Boko Haram Crisis in Northern Nigeria and its Implication on Educational Psychology of School Children and Teachers. Journal of Education and Human Development, 3(2) 361-380

[54] Onukaogu, C. E. (2002) 'A Literature-Based English language Curriculum in Nigerian Schools and Colleges: Some Reflections on Minimum Requirements' In A, Lawal, I, Isiugo-Abanihe, I.N.Ohia (eds) Perspectives on Applied Linguistics in Language and Literature. Lagos: Stirling-Horden. Pp.300-322. 
[55] Orobosa, V. (2019). JAMB \& WAEC Subject Combination For Law 2019/2020' 'ITSJAMBNEWS, November 6, 2018 https://itsjambnews.com.ng/jamb/law-subject-combination/

[56] Ryan, S \& Ryan, D. (n.d.). "What is Literature?" The Academy Foundation-Fundamentals of Literature and Drama. http://dlibrary.acu.edu.au/staffhome/siryan/academy/foundation

[57] Sarkar, I. (n.d.). Problems of teaching English Literature in the Under Graduate Rural Colleges of Assam (INDIA) - A case study with reference to the Colleges of Undivided Goal Para District. Asam, Rural, India. www.cje.ids.czest.pl/.../17738233-PROBLEMS

[58] Saunders, M., Lewis, P. and Thornhill, A. (2009). Research Methods for business students. England: Pearson.

[59] Segun, Mausi (2016). Conflict Keeping Kids Out of School. In 'They Set the School on Fire' Human Rights Watch Report.https://www.hrw.org/report/2016/04/11/they-set-classrooms-fire/attacks-education-northeast-nigeria

[60] Utibe, U. J., \& Agwagah, U. N. (2015). A Decade of Candidates' Performances in NECO-SSCE Mathematics in Nigeria. Journal of Education and Practice, 6(25), 25-29

[61] Wilburne, M., \& Napoli, M. (2008). Connecting Mathematics and Literature: An Analysis of Pre-service Elementary School Teachers' Changing Beliefs and Knowledge. IUMPST: The Journal. 2 (Pedagogy), 1-10 [www.k-12prep.math.ttu.edu]

[62] Williams, D. (1990). English language teaching: An integrated Approach Ibadan: Spectrum.

[63] Vincent. T. (1979). The Teaching of Modern African Poetry' In E. Ubahawke (ed). The Teaching of English Studies. Ibadan, University Press, Ltd.

[64] Yavuz, A. (2014). Teaching and Interpreting Literary Texts: Difficulties of 4th Year ELT Students at a Turkish University. ProcediaSocial and Behavioural Sciences, 158:27-32 DOI: 10.1016/j.sbspro.2014.12.028

[65] Yin, R. K. (1994). Case Study Research: Design and Methods, 2nd Ed., Thousand Oaks, CA: SAGE Publishing. 